JAMP: Jurnal Adminitrasi dan Manajemen Pendidikan Volume 1 Nomor 1 Maret 2018, Hal : 117-123

Tersedia Online di http://journal2.um.ac.id/index.php/jamp/ ISSN $x x x x-x x x x$ (online)

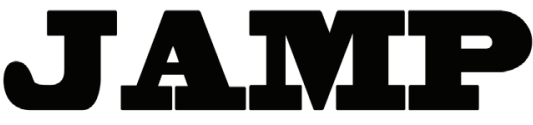

JURNAL ADMINISTRASI DAN MANAJEMEN PENDIDIKAN

\title{
HUBUNGAN KUALITAS PELAYANAN DAN KEPUASAN ANGGOTA KOPERASI MAHASISWA
}

\author{
Hanto Nugroho \\ Djum Djum Noor Benty \\ Juharyanto
}

Email: nugrohohanto@gmail.com

Universitas Negeri Malang, Jl. Semarang No. 5 Malang 65145

\begin{abstract}
This study aims to identify the factors of motivation, explain the most dominant factors, and the degree of each student motivation factor in following the Student Organization (Ormawa) at Faculty of Education (FIP) State University of Malang (UM). This research uses quantitative approach with factor analysis and descriptive. The results of this study are; (1) factors of motivation, are (a) success factors, (b) environmental factors, (c) ability factors, and (d) personality factors; (2) the most dominant factor is the success factor; And (3) the inclination rate of each motivation factor, the first of which is the success factor, the two environmental factors, the three capability factors, and the four personality factors.
\end{abstract}

Keywords: motivation, the student organization

\begin{abstract}
Abstrak: Penelitian ini bertujuan mengidentifikasi faktor-faktor motivasi, menjelaskan faktor paling dominan, dan tingkat kecenderungan masing-masing faktor motivasi mahasiswa mengikuti Organisasi Kemahasiswaan (Ormawa) di Fakultas Ilmu Pendidikan (FIP) Universitas Negeri Malang (UM). Penelitian ini menggunakan pendekatan kuantitatif dengan analisis faktor dan deskriptif. Hasil penelitian ini yaitu; (1) faktor-faktor motivasi, adalah (a) faktor keberhasilan, (b) faktor lingkungan, (c) faktor kemampuan, dan (d) faktor kepribadian; (2) faktor paling dominan adalah faktor keberhasilan; dan (3) tingkat kecenderungan masingmasing faktor motivasi, yang pertama faktor keberhasilan, kedua faktor lingkungan, ketiga faktor kemampuan, dan keempat faktor kepribadian.
\end{abstract}

Kata kunci: motivasi, organisasi kemahasiswaan

Manusia merupakan makhluk individu sekaligus sosial, setiap manusia saling terikat dan bekerja sama untuk mewujudkan tujuannya. Hal ini dapat dikatakan manusia memiliki keterbatasan yang dapat dilengkapi oleh manusia lainnya. Dalam mewujudkan tujuannya, manusia membentuk kelompok atau organisasi. Hicks (dalam Anam, 2006: 61) berpendapat, bahwa "hampir setiap orang dipengaruhi secara mendalam oleh kelompok atau organisasi", sebab dengan usaha secara kelompok, dapat lebih efektif dan efisien dalam mewujudkan sebuah tujuan organisasi. Robbins (1994: 4) menyatakan, bahwa organisasi adalah "kesatuan (entity) sosial yang dikordinasikan secara sadar, dengan sebuah batasan yang dapat diidentifikasi, yang bekerja atas dasar yang relatif terus-menerus untuk mencapai suatu tujuan bersama atau sekelompok tujuan". Apabila sebuah keinginan yang dicapai secara bersama, maka dibutuhkan kesatuan atau kebersamaan untuk meraih tujuan tersebut. Dengan adanya kesatuan yang dikordinasikan secara terstruktur, terencana, dan sistematis diharapkan tujuan dapat direalisasikan.

Mahasiswa yang merupakan salah satu makhluk individu sekaligus sosial, diharapkan mampu mempunyai kemampuan (skill), visi, mental, dan karakter. Sarifudin (dalam Fajrina, 2014: 348) mahasiswa diharapkan mampu mengembangkan kemampuan dan ketrampilannya bukan aktivitas 
perkuliahan akan tetapi dari berbagai jenis kegiatan di dalam kampus, salah satunya menjadi anggota sebuah organisasi. Undang-Undang Nomor 20 Tahun 2003 tentang Sistem Pendidikan Nasional Pasal 12 Ayat $1 \mathrm{~b}$ menyatakan, bahwa "setiap peserta didik pada satuan pendidikan berhak mendapatkan pelayanan pendidikan yang sesuai dengan bakat, minat, dan kemampuannya". Berdasarkan hal tersebut, mahasiswa membutuhkan suatu organisasi yang digunakan untuk mengembangkan pola pikir dalam berorganisasi maupun dalam kehidupan sosial.

Peraturan Rektor Universitas Negeri Malang Nomor 13/Kep/UN32/KM/ 2012 tentang Pedoman Organisasi Kemahasiswaan Universitas Negeri Malang Pasal 1 Ayat 7 menjelaskan, bahwa Organisasi Kemahasiswaan atau yang disebut Ormawa adalah "wahana dan sarana pengembangan diri mahasiswa Universitas Negeri Malang dalam bidang ekstrakurikuler, mencakup aspek penalaran-keilmuan, bakatminat-kegemaran, kepemimpinan dan organisasi, kesejahteraan, dan kepedulian sosial". Hal ini yang harus dilakukan oleh mahasiswa untuk memilih dan menentukan Ormawa sesuai dengan kemauannya. Sehingga, mahasiswa yang bersangkutan mampu untuk meningkatkan kemampuannya dan mendapatkan prestasi. Selain itu, keikutsertaan di Ormawa dapat digunakan sebagai bentuk dari proses pendidikan.

Fakultas Ilmu Pendidikan (FIP) sebagai fakultas yang tertua di Universitas Negeri Malang (UM) mempunyai Ormawa yang bergerak ditingkat fakultas dan jurusan. Fakultas ini merupakan fakultas yang memiliki 3 kampus di daerah berbeda, yakni 2 kampus berbeda di daerah Malang dan 1 kampus di daerah Blitar. Hal inilah, yang menjadi berbeda disetiap Ormawa yang diikuti oleh mahasiswa FIP UM. Berdasarkan yang diadopsi dari Peraturan Rektor Universitas Negeri Malang Nomor 13/Kep/ UN32/KM/ 2012 tentang Pedoman Organisasi Kemahasiswaan Universitas Negeri Malang, Keputusan Dekan FIP UM Tahun 2017 tentang Struktur Kepengurusan Organisasi Kemahasiswaan FIP UM menyatakan, bahwa Ormawa di FIP UM dibedakan Organisasi Pemerintahan Mahasiswa (OPM) dan Organisasi Non Pemerintahan Mahasiswa (ONPM). Organisasi pemerintahan mahasiswa terdiri dari Dewan Mahasiswa Fakultas (DMF), Badan Eksekutif Mahasiswa Fakultas (BEMFA), Himpunan Mahasiswa Jurusan (HMJ), dan Koordinator Kegiatan Mahasiswa 3 (KKM 3). Sedangkan ONPM terdiri dari Unit Aktivitas Sentuhan Ruhani Islam (UA Seruni), Unit Aktivitas Mahasiswa Peneliti dan Penulis Produktif (MP3), Unit Aktivitas Organisasi Pecinta Seni FIP UM (UA OPIUM), Unit Aktivitas Sport Education Faculty (UA Spion Duty), dan Unit Aktivitas Study Center and Service of Disabilities (UA SCSD). Adanya Ormawa ini diharapkan, dapat menampung dan menyalurkan aspirasi, forum komunikasi, dan koordinasi untuk pengemabangan mahasiswa, peningkatan ketrampilan manajemen serta menumbuhkan sikap profesional yang mandiri. Dengan begitu mahasiswa dapat melatih kepekaan sosial dan bertanggungjawab atas tindaknya.

Penelitian yang dilakukan Anam (2006: 75) menyatakan, bahwa "mahasiswa yang berpartisipasi aktif dalam Ormawa FIP berada dalam taraf sedang. Hal ini dikarenakan, Ormawa FIP belum mampu membangun citra positif menyangkut kegiatan dengan mahasiswanya". Adanya temuan tersebut, bahwasannya Ormawa belum mampu membangun citra positif terhadap mahasiswa FIP. Apabila mahasiswa memandang Ormawa tersebut belum memiliki citra posistif, maka dapat berdampak terhadap kemauan mahasiswa untuk mengikuti Ormawa. Hal ini yang harus dilakukan Ketua Ormawa untuk menumbuhkan motivasi mahasiswa untuk mengikuti Ormawa. Ada beberapa faktor motivasi mahasiswa mengikuti Ormawa di FIP UM, seperti dari diri sendiri ataupun lingkungannya. Tanpa adanya motivasi, mahasiswa acuh tak acuh untuk mengikuti Ormawa.

Menurut Donald (dalam Hamalik, 2011: 106), bahwa motivasi adalah "perubahan energi dalam diri seseorang yang ditandai dengan timbulnya perasaan dan reaksi untuk mencapai tujuan". Dengan begitu mahasiswa yang mengikuti Ormawa, mempunyai dorongan yang kuat untuk memilih dan menentukan Ormawa sesuai dengan potensi dirinya. Sardiman (2001: 87) mengemukakan motivasi dapat dibedakan menjadi 2 golongan, yaitu: motivasi intrinsik dan motivasi ektrinsik. Motivasi intriksik adalah motifmotif yang menjadi aktif atau berfungsi yang tidak perlu dirangsang dari luar, karena dalam diri setiap individu sudah ada dorongan untuk melakukan sesuatu. Motivasi ekstrinsik adalah motif-motif yang aktif yang berfunsi karena adanya perangsang dari luar. 
Motivasi mahasiswa dalam mengikuti Ormawa di FIP, dapat termotivasi secara intrinsik dan ekstrinsik maupun keduanya. Adanya motivasi tersebut mahasiswa terdorong untuk aktif mengikuti Ormawa. Motivasi intrinsik merupakan keinginan yang kuat untuk belajar dan mengembangkan kemampuan di dalam Ormawa. Sementara motivasi ekstrinsik berasal dari orang-orang yang selalu mendukung untuk berkembang. Berdasarkan latar belakang, maka perlu dilakukan penelitian dengan judul 'Analisis Faktor-Faktor Motivasi Mahasiswa Mengikuti Organisasi Kemahasiswaan di Fakultas Ilmu Pendidikan Universitas Negeri Malang'.

\section{METODE}

Penelitian ini menggunakan pendekatan kuantitatif dengan rancangan analisis faktor dan deskriptif. Penelitian ini menggunakan sampel dari populasi mahasiswa yang mengikuti Ormawa di FIP UM, yakni sebesar 514 mahasiswa. Pengambilan sampel menggunakan rumus Slovin (Setyadin, 2005: 20) diperoleh sebesar 225 dengan menggunakan toleransi peluang error 0,05 . Jenis data yang digunakan adalah data ordinal (skala likert) yang kemudian ditransformasikan menjadi data interval melalui Method Successive Internal dan dihitung menggunakan dengan Statistical Package for the Social Science for windows versi 21.0.

Penelitian ini menggunakan jenis angket tertutup dan disertai dengan jawaban yang telah disediakan. Hal ini dikarenakan, memberikan kemudahan kepada responden untuk menjawab dengan cepat dan mempermudah dalam menyimpulkan angket tertutup. Bentuk jawaban angket tertutup, yaitu "kuesioner yang disusun dengan menyediakan pilihan jawaban lengkap, sehingga responden tinggal memberi tanda pada jawaban yang dipilih" (Wiyono, 2007: 50).

Teknik analisis data yang digunakan yaitu analisis faktor dan deskriptif. Setyadin (2005: 2) mengemukakan, bahwa analisis faktor merupakan "teknik statistik untuk megidentifikasi faktorfaktor dalam jumlah kecil yang dapat mewakili seperangkat variabel laten yang saling berhubungan". Sedangkan Sugiyono (2011: 147) menjelaskan, bahwa "statistik deskriptif adalah statistik yang digunakan untuk menganalisa data dengan cara mendeskripsikan atau menggambarkan data yang telah terkumpul sebagaimana adanya bermaksud membuat kesimpulan yang berlaku untuk umum atau generalisasi". Teknik analisis tersebut digunakan guna mengidentifikasi faktor-faktor dari beberapa indikator dan mempermudah pembacaan serta penyimpulan terhadap faktor-faktor motivasi mahasiswa mengikuti Ormawa di FIP UM.

\section{HASIL}

Ada dua faktor motivasi mahasiswa mengikuti Ormawa di FIP UM, yakni motivasi secara intrinsik dan ekstrinsik. Adapun hasil dari motivasi mahasiswa secara intrinsik dan ekstrinsik, dapat dilihat pada Gambar 1. Hasil dari penelitian ini mengidentifikasi, bahwa mahasiswa yang termotivasi secara intrinsik sebesar $57,096 \%$ dan sebesar $42,903 \%$ termotivasi secara ekstrinsik.

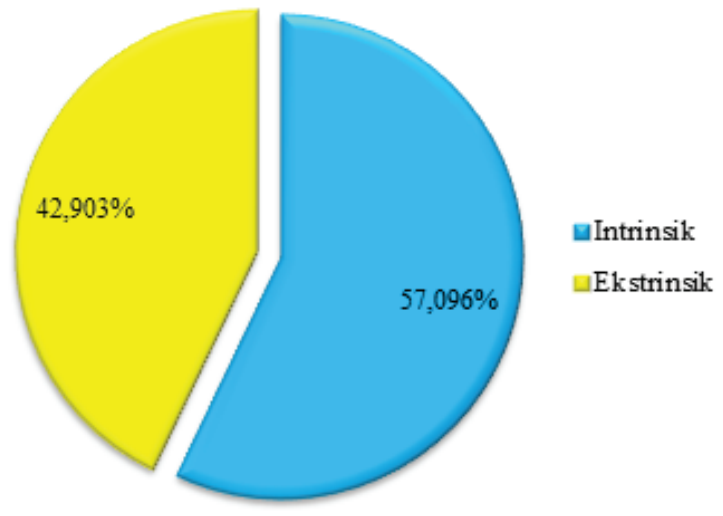

Gambar 1 Motivasi Mahasiswa secara Intrinsik dan Ekstrinsik 
Berdasarkan uji analisis faktor yang dilakukan dengan SPSS for windows versi 21.0 mengidentifikasi 4 kelompok. Adapun indentifikasi dapat dilihat pada Tabel 1.

Tabel 1 Identifikasi Temuan Faktor

\begin{tabular}{cccc}
\hline No. & Nama Faktor & Egien Value & $\%$ Variance \\
\hline 1 & Faktor keberhasilan & $\mathbf{2 5 , 3 7 2}$ & $14,336 \%$ \\
2 & Faktor lingkungan & $\mathbf{8 , 1 6 5}$ & $12,033 \%$ \\
3 & Faktor kemampuan & 5,572 & $\mathbf{8 , 5 3 1 \%}$ \\
4 & Faktor kepribadian & 4,220 & $\mathbf{8 , 4 2 9 \%}$ \\
\hline & Jumlah & 43,329 & $43,329 \%$ \\
\hline
\end{tabular}

Berdasarkan paparan Tabel 1, dapat diketahui dari 225 responden mengemukakan faktor yang mempunyai presentase terbesar yaitu $25,372(14,336 \%)$ pada faktor 1 , faktor 2 sebesar $8,165(12,033 \%)$, fakor 3 sebesar 5,572 (8,531\%), dan faktor 4 sebesar 4,220 (8,429\%). Hal tersebut dapat disimpulkan, bahwa terdapat 4 faktor yang memotivasi mahasiswa mengikuti Ormawa di FIP UM. Keempat faktor tersebut, adalah (1) faktor keberhasilan, (2 ) faktor lingkungan, (3) faktor kemampuan, dan (4) faktor kepribadian.

Faktor dominan merupakan faktor yang paling banyak memiliki frekuensi pernyataan sangat setuju pada tiap-tiap kelompok faktor. Hal ini dikarenakan, bahwa mahasiswa merasa sangat setuju kelompok faktor tersebut yang dapat memotivasi dalam mengikuti Ormawa di FIP UM. Adapun hasil dari dominasi analisis faktor, dapat dilihat pada Gambar 2.

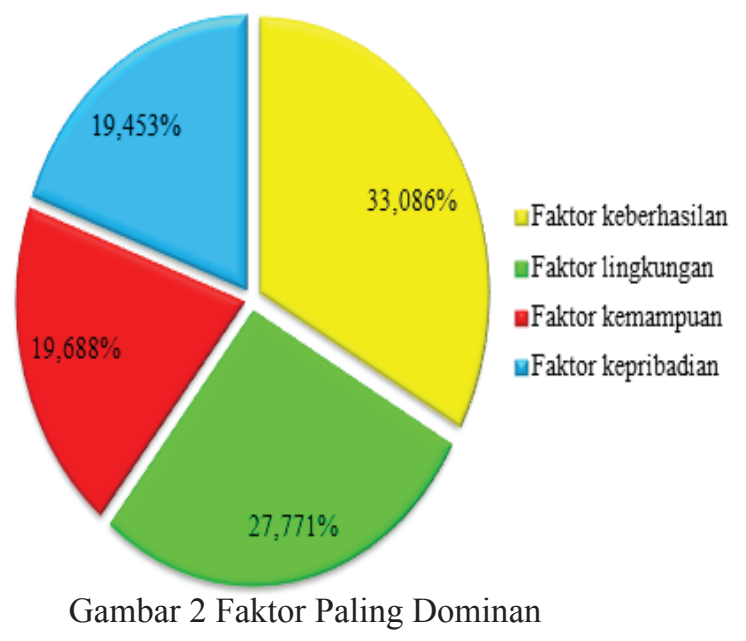

Berdasarkan Gambar 2, bahwa faktor motivasi mahasiswa yang paling dominan mengikuti Ormawa di FIP UM adalah faktor keberhasilan dengan persentase sebesar 58,556\%. Faktor lingkungan dengan persentase sebesar 18,844\%. Faktor kemampuan dengan persentase sebesar $12,859 \%$. Faktor kepribadian dengan persentase sebesar 9,739\%.

Setelah dilakukan analisis faktor, kemudian dilakukan dengan mendeskripsikan besaran masingmasing faktor motivasi mahasiswa mengikuti Ormawa di FIP UM. Adapun hasil dari analisis deskriptif terhadap faktor tersebut adalah faktor keberhasilan termasuk dalam kategori 'sedang', dengan rata-rata sebesar 1,53 dan persentase sebesar 52,444\%. Faktor lingkungan termasuk dalam kategori 'sedang', dengan rata-rata sebesar 1,55 dan persentase sebesar 52,000\%. Faktor kemampuan termasuk dalam kategori 'sedang', dengan rata-rata sebesar 1,96 dan persentase sebesar 77,778\%. Faktor kepribadian termasuk dalam kategori 'tinggi', dengan rata-rata sebesar 1,37 dan persentase sebesar $63,556 \%$. 


\section{PEMBAHASAN}

Berdasarkan hasil tersebut, bahwa mahasiswa mengikuti Ormawa di FIP UM menyatakan terdapat empat faktor yang memotivasinya. Faktor keberhasilan merupakan salah satu faktor yang memotivasi. Faktor ini sesuai dengan teori yang diungkapkan oleh Maslow, Clelland, Herzberg, dan Skinner. Menurut Maslow (dalam Saleh, 2008: 190), bahwa mahasiswa mengikuti Ormawa di FIP UM termotivasi akan kebutuhan prestasi. Menurut Clelland (dalam Robbins 2008: 230), bahwa mahasiswa mengikuti Ormawa di FIP UM termotivasi akan kebutuhan mencapai standar-standar dan berusaha keras untuk berhasil. Sementara itu, Herzberg (dalam Robbins, 2008: 227) mengemukakan, bahwa mahasiswa mengikuti Ormawa di FIP UM termotivasi akan kebutuhan prestasi. Sedangkan menurut Skinner (dalam Thobroni, 2013: 77), bahwa mahasiswa mengikuti Ormawa di FIP UM termotivasi dengan adanya penguatan yang diberikan kepadanya.

Kebutuhan ini berhubungan dengan pencapaian keberhasilan program kerja selama masa kepengurusan. Adanya faktor ini pengurus Ormawa di FIP UM akan berusaha semaksimal mungkin untuk mencapai tujuan yang telah terencana. Mereka dapat menerima umpan balik yang cepat atas kinerja selama ini, sehingga dapat mengetahui dengan mudah kinerja yang telah dilakukan. Selain itu, mereka juga memiliki tujuan yang realistik, serta memiliki persaudaraan yang erat dalam merealisasikan tujuannya. Apabila sebuah Ormawa dalam merencanakan program kerja selama masa kepengurusan tanpa mengindahkan ataupun mencerminkan kemampuannya, maka dikemudian hari akan berdampak pada program kerja diakhir masa kepengurusan. Semisal sebuah Ormawa merencanakan program kerja A, B, C, D dan tidak mengindahkan kemampuan dalam Ormawa tersebut, maka dikemudian hari program tersebut hanya terealisasi sebagian ataupun tindak mencapai target. Hal inilah yang perlu diperhatikan oleh Ormawa dalam merencanakan program kerja, mengingat keberhasilan program kerja menjadi pencapaian tujuan sebuah organisasi.

Mahasiswa yang termotivasi secara faktor lingkungan. Faktor ini sesuai dengan teori yang diungkapkan oleh Maslow, Clelland, Herzberg, dan Skinner. Menurut Maslow (dalam Saleh, 2008: 190), bahwa mahasiswa mengikuti Ormawa di FIP UM termotivasi akan kebutuhan ingin dicintai, diperhitungkan secara pribadi, diakui sebagai kelompok, serta rasa setia kawan dan kerja sama. Menurut Clelland (dalam Robbins 2008: 230), bahwa mahasiswa mengikuti Ormawa di FIP UM termotivasi untuk menjalin suatu hubungan antarpersonal yang ramah dan akrab. Sementara itu, Herzberg (dalam Robbins, 2008: 227) mengemukakan, bahwa mahasiswa mengikuti Ormawa di FIP UM termotivasi untuk menjalin hubungan dengan teman sejawat atau kolegial. Sedangkan menurut Skinner (dalam Thobroni, 2013: 77), bahwa mahasiswa mengikuti Ormawa di FIP UM termotivasi dengan adanya penguatan yang diberikan kepadanya.

Kebutuhan ini merupakan kebutuhan yang dapat menunjang keberhasilan dalam mencapai tujuan, yakni kebutuhan akan lingkungan. Kebutuhan ini diperlukan oleh setiap mahasiswa yang mengikuti Ormawa di FIP UM. Adanya hubungan yang baik antar personal ataupun antar subdivisi, menambah nilai plus dalam merealisasikan program kerja. Apabila terdapat seseorang dalam Ormawa tersebut tidak begitu aktif dalam fungsional ataupun kepanitiaan, maka dapat berdampak tidak baik terhadap pengurus yang lainnya. Semisal terdapat 2 pengurus Ormawa yang tidak aktif dalam kegiatan, maka dapat berdampak pada kepanitiaan yang terjadi, sehingga berdampak pada kepengurusan selama setahun. Hal inilah yang perlu diperhatikan, mengingat keharmonisan sebuah Ormawa dapat mengadakan dan menyukseskan kegiatan yang besar. Ketika terjadi hal tersebut, dilakukan oleh Ketua Ormawa bicara langsung kepada pihak yang bersangkutan guna menemukan suatu masalah. Hal ini diperlukan, guna meminimalisir kemungkinan-kemungkinan terburuk yang terjadi pada pengurus lainnya.

Faktor yang selanjutnya memotivasi mahasiswa mengikuti Ormawa di FIP UM adalah faktor kemampuan. Faktor ini sesuai dengan teori yang diungkapkan oleh Maslow, Clelland, Herzberg, dan Skinner. Menurut Maslow (dalam Saleh, 2008: 190), bahwa mahasiswa mengikuti Ormawa di FIP UM termotivasi akan kebutuhan kemampuan, mempertinggi potensi-potensi yang dimiliki, mengembangkan diri secara maksimum, kreativitas, dan ekspresi diri. Menurut Clelland (dalam Robbins 2008: 230), bahwa mahasiswa mengikuti Ormawa di FIP UM termotivasi akan kebutuhan melebihi standar-standar 
yang telah direncanakan. Sementara itu, Herzberg (dalam Robbins, 2008: 227) mengemukakan, bahwa mahasiswa mengikuti Ormawa di FIP UM termotivasi pengakuan, kerja itu sendiri, kemajuan dan pertumbuhan diri sendiri. Sedangkan menurut Skinner (dalam Thobroni, 2013: 77), bahwa mahasiswa mengikuti Ormawa di FIP UM termotivasi dengan adanya penguatan yang diberikan kepadanya.

Kebutuhan ini untuk merealisasikan program kerja yang telah direncanakan. Apabila semakin tinggi kemampuan pengurus Ormawa, maka semakin tinggi pula pencapaian target yang harus dicapai. Begitu juga sebaliknya semakin rendah kemampuan pengurus Ormawa, maka rendah pula pencapaian target yang direncanakan. Namun terkadang dengan kemampuan yang rendah dapat mencapai hasil yang tinggi. Hal ini disebabkan oleh penguatan yang diberikan oleh Ketua Ormawa. Penguatan ini berupa penguatan yang bersifat positif, dimana diberikan ketika pengurus Ormawa dapat menyelesaikan tugasnya diatas target. Pujian tersebut berakibat mendapat rasa kepercayaan yang tinggi. Oleh karenanya pengurus tersebut menyenangi konsekuensi perilakunya dan berusaha meningkatkan kemampuannya, sehingga mendapat konsekuensi positif dikemudian hari.

Selanjutnya faktor yang terakhir memotivasi mahasiswa mengikuti Ormawa di FIP UM adalah faktor kepribadian. Faktor ini sesuai dengan teori yang diungkapkan oleh Maslow, Clelland, Herzberg, dan Skinner. Menurut Maslow (dalam Saleh, 2008: 190), bahwa mahasiswa mengikuti Ormawa di FIP UM termotivasi akan kebutuhan sosial, penghargaan, dan aktualisasi diri. Menurut Clelland (dalam Robbins 2008: 230), bahwa mahasiswa mengikuti Ormawa di FIP UM termotivasi akan kebutuhan untuk membuat individu lain berperilaku sedemikian rupa sehinga mereka mereka tidak akan berperilaku sebaliknya. Sementara itu, Herzberg (dalam Robbins, 2008: 227) mengemukakan, bahwa mahasiswa mengikuti Ormawa di FIP UM termotivasi akan tanggung jawab. Sedangkan menurut Skinner (dalam Thobroni, 2013: 77), bahwa mahasiswa mengikuti Ormawa di FIP UM termotivasi dengan adanya penguatan yang diberikan kepadanya.

Kebutuhan ini mencerminkan kepribadian seorang pengurus Ormawa di FIP UM. Adanya kebutuhan kepribadian ini dapat memberikan suri tauladan kepada mahasiswa lainnya, seperti tanggung jawab akademik dan organisasi. Hal inilah yang harus dipertahakan oleh pengurus Ormawa, selain aktif diorganisasi juga mempunyai prestasi akademik. Selain itu, seseorang pengurus Ormawa di FIP UM memiliki kepribadian untuk mempengaruhi dan mengendalikan pikiran ataupun tindakan pengurus lainnya sesuai dengan keinginannya. Hal tersebut, dapat disimpulkan bahwa faktor kepribadian pengurus dapat mempengaruhi dan mengendalikan pengurus lainnya.

\section{KESIMPULAN DAN SARAN}

\section{Kesimpulan}

Berdasarkan hasil penelitian dan pembahasan yang telah diuraikan dapat diperoleh kesimpulan, antara lain: (1) faktor-faktor motivasi mahasiswa mengikuti Organisasi Kemahasiswaan (Ormawa) di Fakultas Ilmu Pendidikan (FIP) Universitas Negeri Malang (UM) dapat dilaporkan sebagai berikut: (a) faktor keberhasilan, (b) faktor lingkungan, (c) faktor kemampuan, dan (d) faktor kepribadian. Keempat faktor tersebut merupakan faktor pengembangan dari motivasi intrinsik dan ekstrinsik yang telah dilakukan pengolahan data dengan analisis faktor; (2) faktor yang paling dominan mengikuti Ormawa di FIP UM adalah faktor keberhasilan. Faktor ini cenderung diminati banyak mahasiswa, karena memberikan kesempatan untuk menghadapi tantangan yang menuntut tanggung jawab pribadi yang tinggi, keberanian mengambil resiko, pencapaian tujuan realistik, dan usaha untuk memperjuangkan keinginan mencapai tujuan; dan (3) tingkat kecenderungan masing-masing faktor motivasi mahasiswa mengikuti Ormawa di FIP UM yang pertama adalah faktor keberhasilan, kedua adalah faktor lingkungan, ketiga adalah faktor kemampuan, dan keempat adalah faktor kepribadian. Keempat faktor tersebut, memotivasi mahasiswa dalam mengikuti Ormawa di FIP, namun dengan kontribusi yang berbeda-beda. 


\section{Saran}

Berdasarkan kesimpulan, maka peneliti memberikan saran, kepada (1) Wakil Dekan Bagian Kemahasiswaan dan Alumni FIP UM, hendaknya melakukan pertimbangan dalam mengambil keputusan yang dapat memotivasi mahasiswa agar mau mengikuti Ormawa di FIP UM; (2) Ketua Jurusan Administrasi Pendidikan, hendaknya memperkenalkan kepada para mahasiswa bahwa dengan mengikuti organisasi dapat memberikan manfaat bagi dirinya maupun masyarakat sekitarnya, seperti mengembangkan sikap, kepribadian, pengetahuan, dan ketrampilan manajerial organisasi. Dengan begitu, kelak mahasiswa dapat menjadi pemimpin yang mempunyai kemampuan sesuai tuntutan masyarakat di masa mendatang; (3) Ketua Ormawa FIP UM, hendaknya memberikan penguatan kepada mahasiswa yang mengikuti Ormawa di FIP UM. Sehingga Ketua Ormawa di FIP UM mampu memadukan faktorfaktor mahasiswa yang mengikuti Ormawa untuk mencapai tujuan organisasi; (4) Pengurus Ormawa FIP UM, hendaknya meningkatkan faktor motivasi yang kurang pada dirinya. Dengan begitu, mereka mampu untuk mengembangkan faktor yang kurang pada dirinya; dan (5) Peneliti lain, bahwa penelitian ini hanya meneliti tentang motivasi mahasiwa mengikuti Ormawa di FIP. Hendaknya peneliti lain dapat mengembangkan penelitian ini dengan meneliti keseluruhan Ormawa yang ada di UM. Dengan begitu, dapat memberikan gambaran tentang motivasi mahasiswa mengikuti Ormawa di UM.

\section{DAFTAR RUJUKAN}

Anam, K. 2006. Hubungan Persepsi dan Minat Berorganisasi dengan Partisipasi Berorganisasi Mahasiswa. Jurnal Manajemen Pendidikan, 19 (1): 61-75.

Fajrina, A. D. dan Rosiana, D. 2014. Hubungan Flow dengan Psychological Well-Being Mahasiswa Psikologi Unisba yang Aktif Organisasi. (Online), (http://karyailmiah.unisba.ac.id/index.php/psikologi/article/ dowload/1292/pdf), diakses pada 11 Januari 2017.

Hamalik, O. 2011. Kurikulum dan Pembelajaran. Jakarta: Bumi Aksara.

Keputusan Dekan Fakultas Ilmu Pendidikan Tahun 2017 tentang Struktur Kepengurusan Organisasi Kemahasiswaan Fakultas Ilmu Pendidikan Universitas Negeri Malang. 2017. Malang: Fakultas Ilmu Pendidikan UM.

Peraturan Rektor Universitas Negeri Malang Nomor 13/Kep/UN32/KM/2012 tentang Pedoman Organisasi Kemahasiswaan Universitas Negeri Malang. 2012. (Online), (http://kemahasiswaan.um.ac.id/wp-content/ uploads/2013/05/SK-ORMAWA-2012-Final-TDD-File-Rektor.rtf), diakses 22 Februari 2016.

Robbins, S. P. 1994. Teori Organisasi: Struktur, Desain \& Aplikasi. Terjemahan Jusuf Udaya. Jakarta: Arcan.

Robbins, S. P. dan Timothy, A. J. 2008. Perilaku Organisasi. Terjemahan Diana Angelica. Jakarta: Salemba Empat. Sardiman, A. M. 2001. Interaksi dan Motivasi Belajar Mengajar. Jakarta: Rajawali Press.

Setyadin, B. 2005. Modul 2a Reduksi Data Melalui Analisis Faktor Eksploratori. Malang: Lembaga Penelitian Universitas Negeri Malang.

Setyadin, B. 2005. Modul I: Dasar-Dasar Penelitian Ilmiah. Malang: Lembaga Penelitian Universitas Negeri Malang.

Shaleh, A. R. 2008. Psikologi: Suatu Pengantar dalam Perspektif Islam. Jakarta: Kencana.

Sugiyono. 2011. Metode Penelitian Kuantitatif, Kualitatif, dan R\&D. Bandung: Alfabeta.

Thobroni, M. dan Mustofa, A. Belajar dan Pembelajaran: Pengembangan Wacana dan Praktik Pembelajaran dalam Pembangunan Nasional. Jogjakarta: Ar-Ruzz Media.

Undang-Undang Nomor 20 Tahun 2003 tentang Sistem Pendidikan Nasional. 2013. Bandung: Citra Umbara.

Wiyono, B. B. 2007. Metodologi Penelitian (Pendekatan Kuantitatif, Kualitatif, dan Action Research) (Burhannuddin, Ed.). Malang: Fakultas Ilmu Pendidikan Universitas Negeri Malang. 